\title{
Ecological problems related to the safe processing of dairy raw materials and whey
}

\author{
Irina Buyanova ${ }^{1,{ }^{*}}$, Marina Kurbanova $^{1}$, Lev Ostroumov $^{1}$, and Olesya Kalugina ${ }^{1}$ \\ ${ }^{1}$ Technologial Institute of Food Industry, Kemerowo State University, 6, str. Krasnaya, 650043, \\ Kemerowo, Russia
}

\begin{abstract}
A significant number of milk processing companies all over the world confront the challenge of whey recycling. To date, the processing of milk results in a considerable amount of waste products, which can be used in core production processes, for the output of additional products and can help neutralize harmful effects of milk processing waste waters on the environment. This factor emphasizes the relationship between food and environment. The extraction of water from cheese and curd whey in the manufacture of concentrates gives a solution to one of the challenges facing the dairy industry - the processing of secondary dairy raw resources. Whey concentrates have certain advantages because they are long-shelf-life and easy-to-transport products of high nutritional and biological value. Several studies have assessed process flow factors of whey dehydrating in the manufacture of whey concentrates. The research was carried out using an experimental unit of a vacuum dryer with the thermal radiation power supply. The concentrates with a percentage of dry substances ranging from 11 to $30 \%$ were produced. The important outcomes to emerge from the study are data on the dynamics of vacuuminduced water extraction from cheese and curd whey, its appropriate modes, as well as regularities and specifics of water removal. The quality of concentrates was assessed according to key parameters. The organoleptic properties of sample concentrates met all criteria quite sufficiently, being similar to input parameters. Whey concentrates with a mass fraction of dry substances from 11 to $30.0 \%$ are recommended to use in recipe compositions of fresh and fermented whey-containing drinks. IRrays represent a good alternative to conventional thickening and drying processes of raw materials at high processing temperatures. The properties of input raw materials remain unaffected owing to non-destructive temperature modes of the vacuum dryer.
\end{abstract}

\section{Introduction}

Traditionally organized industrial milk processing and production of butter, cheese, curd, casein and other dairy products are closely related to by-products, e.g. low-fat milk, buttermilk and whey, all of them can be described by a conditional generic term secondary raw materials.

\footnotetext{
*Corresponding author: ibuyanova@@mail.ru
} 
Approximately $50 \%$ of dry substances in milk are transferred into whey in the production of cheese, curd and casein; the highest share of them belongs to lactose (up to $70 \%$ ). A biological value of these secondary raw materials stems from the considerable concentration of protein substances $(0.8 \%)$ represented mainly (about $90 \%$ ) by whey protein fractions (lactalbumin, lactoglobulin), which stimulate the fermentation capacity of the human digestive system and can be considered as an additional source of essential amino acids in the product $[1,2]$.

It is a well-known fact, that almost all macro-and microelements of milk as a regular solution are transferred into whey. Salts of organic and non-organic acids build a colloidal phase. The water-soluble vitamins are totally transferred into secondary raw materials when manufacturing a main product. It has been established that their concentration is much higher in cheese whey than in curd whey $[1,2]$.

A biological value of whey protein is similar to that of fish, exceeding, however, the value of casein - a main milk protein - and grain. Fractions of whey proteins are characterized by a high content of an essential sulfur-containing amino acid - cysteine (seven-nineteen times higher than in casein). In their natural form albumin and globulin are equal to chicken protein accepted to be an ideal protein because of its value. In addition, the number of free amino acids in cheese and curd whey is six-nine times higher than in milk.

Such well-known scientists as A.G. Khramtsov, P.G. Nesterenko, A.V. Onopriyko, A.A. Khramtsova, I.A. Evdokimova, S.V. Vasilisina, S.A. Ryabtseva, etc. are involved into the research and development of innovative processing technologies of secondary raw materials in Russia. The present-day research is focused on biologically active whey proteins (peptides), which are biologically active substances and act as immune-response modifiers in human nutrition $[1,2,3]$.

To date, whey recycling is an urgent problem to face a majority of milk-processing companies all over the world. In Russia, for instance, the annual output of whey by milkprocessing plants approximates to 3 million tons, nevertheless, only $30 \%$ of this byproduct is recycled, while the rest is returned to agricultural producers and discharged as wastewaters into the environment. This factor emphasizes the important relation between food products and nature. Nutrition seems to be an important factor connecting a human being with the environment.

The recycling of secondary raw materials, e.g. whey, represents a burning issue. This challenge faces numerous milk-processing companies in the world. The amount of whey, a by-product in the production of cheese and curd, ranges to 3 million tons per year, but only $30 \%$ of this amount is recycled. The remaining part is discharged as wastewaters or supplied back to agricultural producers. This fact points at the important connection between the food production and environment. Therefore, nutrition is thought to be an important factor linking a human being with the environment.

Milk and dairy products easily adsorb on their surfaces various pollutants that penetrate into them in case of violating sanitary rules and standards stated in regulatory documents. The biological safety of milk and dairy products is viewed from the environmental and ecological perspectives. At the same time, there is a second, inverse relationship, i.e. milkprocessing companies influence the environment, to be more precise, their wastewaters have a harmful effect on nature. The industry has to find a solution and minimize a dangerous environmental impact $[4,5,6,7,8,9]$.

The biological state of soil, water and air considered as factors of industrial ecology, will affect food products, e.g. milk, through the type of used raw materials and production technologies. Furthermore, a pollution degree of dairy raw materials determines such important factors as the absence of foreign substances in plants and animal health. Technological equipment and processing modes, the sanitary state of water and workforce are seen as factors relevant for the safety of products. 
The state program on the production of safe and healthy products says that particular attention is to be paid to issues of environment protection, to the use of production waste and development of measures to improve the environment. A problem of quality is of special concern, especially if raw materials are sold and used directly, without milkprocessing plants and under violation of sanitary and veterinary standards.

The dairy sector is a critical factor in the technical implementation of innovative technologies, based on an in-depth analysis of possible consequences arising from the use of new raw materials and chemicals, and the introduction of new equipment operated according to non-traditional processing methods.

In such critical situations it is necessary to take into consideration certain factors related to the technical introduction of innovative technologies. An in-depth analysis is to be carried out to reveal probable consequences of applying new raw materials, chemicals, and installing new technological equipment within unconventional processing methods.

It should be noted that dairies are a part of the biosphere. Dairy plants consume such natural factors as water and air; the relationship between all components of the environment is shown in Figure $1[4,8]$.

The escalation of environmental problems associated with the technology of milk and dairy products necessitates a careful study of certain processing techniques and the use of secondary raw materials in order to increase the output of dairy products from a unit of raw materials. In addition, power and raw material inputs are necessary for the production of a finished product. All these components, once in production, undergo certain changes. As a result, a finished product is obtained. At the same time, huge amounts of waste heat and natural components untreated or treated partially are returned into the environment. Only a small percentage of contaminated natural components are recycled and fed back into the main production process.

Currently, the greening of dairy industry is totally unsatisfactory. Comprehensive scientific studies on the ecology of milk and dairy products are needed.

Scientific studies have established that an uncertain amount of foreign substances penetrate a human body (40-50\% with food; 20-40\% with water) [4, 5]. In this consequence, the quality of milk and dairy products unlike any other food is a critical and important issue because they are a compulsory component in the diet of people of all age groups, including children.

The safety of food products in Russia is regulated by certain documents (Federal Law \#№ 88-FZ , issued in 2008, Technical Regulation of the Customs Unit "On the safety of milk and dairy products" (TR TS 033/2013), which specify permitted levels of potentially dangerous toxic substances in milk, whey, buttermilk $(\mathrm{mg} / \mathrm{kg})$ : lead -0.3 , cadmium -0.1 , arsenic -0.15 , mercury -0.015 , aflatoxin $\mathrm{M}_{1}-0.0005$, DDT -0.05 , $\mathrm{HCH}-0.05$; inhibitory substances are not allowed. 


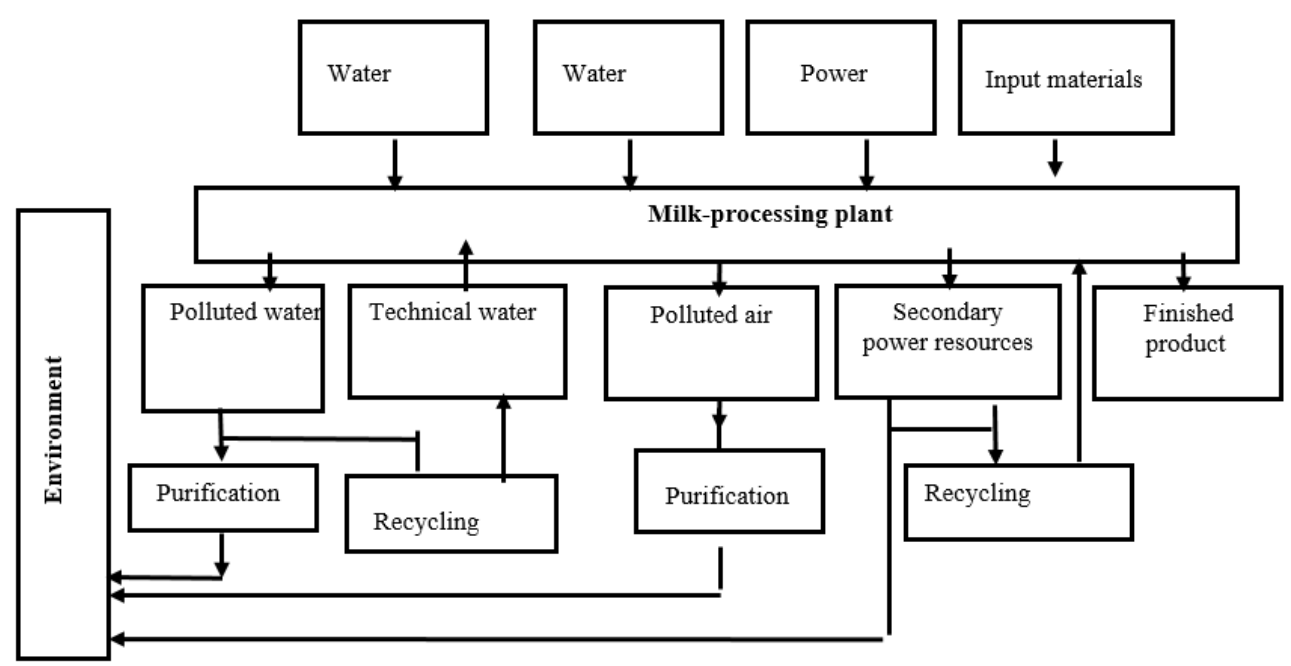

Fig. 1. A diagram representing the relation between a milk-processing company and the environment.

A majority of milk-processing plants are confronting with the challenge of rational whey using. The branch standard BS 10-02-02-3-87 "Milk whey" regulates properties and composition of whey, which can be used in quality assessment.

The global and advanced domestic experience shows that it is the complex industrial recycling of whey that can provide a solution to the efficient use of secondary raw materials. This approach based on the principles of wasteless technologies can increase the output of biologically valuable products, improve technical and economic parameters of milk-processing plants due to the offering additional products from a unit of raw materials and reducing their cost price, make milk processing more environmentally friendly and reduce the environmental pollution by milk components [10,11, 12, 13, 14].

The biochemical processes arising in the fermentation of lactose and rapidly growing acidity make whey spoil quickly; the excessive acidity limits its using in natural form. In this regard, it will be more rational to use whey in the production of concentrates and dry semi-finished products - ingredients for the manufacture of pharmaceuticals, cosmetics and for the production of feed and feed additives $[1,2,14,15,16]$.

The dietary properties and nutritional value of whey are well known, so it is used untreated or pretreated in the production of various drinks. Furthermore, whey is enriched currently via biological treatment, with fruit and berry additives and all whey constituents. The whey dehydration represents a solution to one of the dairy industry's major challenges in the processing of secondary raw materials. It helps produce concentrates, widen the range of products and increase the output using available raw materials.

The most rational method of water extraction ensuring a high quality product and low energy costs is vacuum dehydration with infrared energy supply (thermal radiation). Previous studies have demonstrated that the concentration of whey based on vacuum and thermal radiation is a most up to date method to keep the quality stable [17]. At the same time, this non-traditional method is an effective way to concentrate raw milk in terms of technical and economic indicators.

Since the vacuum and thermal radiation method of dewatering has not been investigated in details, it is a promising research domain for future studies. This study aims to investigate technological factors of whey thickening in the manufacture of whey concentrates and the development of their application technologies. 


\section{Materials and Methods}

The study used curd and cheese whey, as well as whey-containing drink "Aktual" with orange and carrot juice. The object was studied in view of quality criteria according to the State Russian Standard (GOST 34352-2017 "Milk whey - raw materials. Technical conditions") and TR TS 033/2013 [4, 13]. The study was focused on the chemical composition, organoleptic, physical and chemical properties of input whey supplied by different producers. The study was carried out using conventional standard methods:

- preparing and selecting samples according to the State Russian Standard (GOST 26809-86);

- assessing the protein fraction according to the State Russian Standard (GOST 2517990);

- determining the fraction of dry substances according to the State Russian Standard (GOST 3626-73);

- evaluating titratable acidity by a standard method in Turner's degrees according to the State Russian Standard (GOST 3624-92);

The processing of samples was carried out by standard methods of microbiological analysis (GOST R 53430 - 2009). The quality was evaluated in view of organoleptic criteria using a developed 10 point - ranking scale. The requirements specified in the GOST 28283-89 were taken into account for this purpose. The 10 point - ranking scale had certain levels: taste and flavor -5 points, appearance and consistency -3 points, colour -2 points, total score -10 points.

An experimental unit of vacuum dryer with thermal radiation power supply was used to test process flow patterns of whey dewatering. It consisted of the following elements: vacuum pump 1 , drying chamber 2 , refrigerating machine 4 , desublimator 6 , adjusting and measuring systems. The experimental unit is shown in Figure 2.

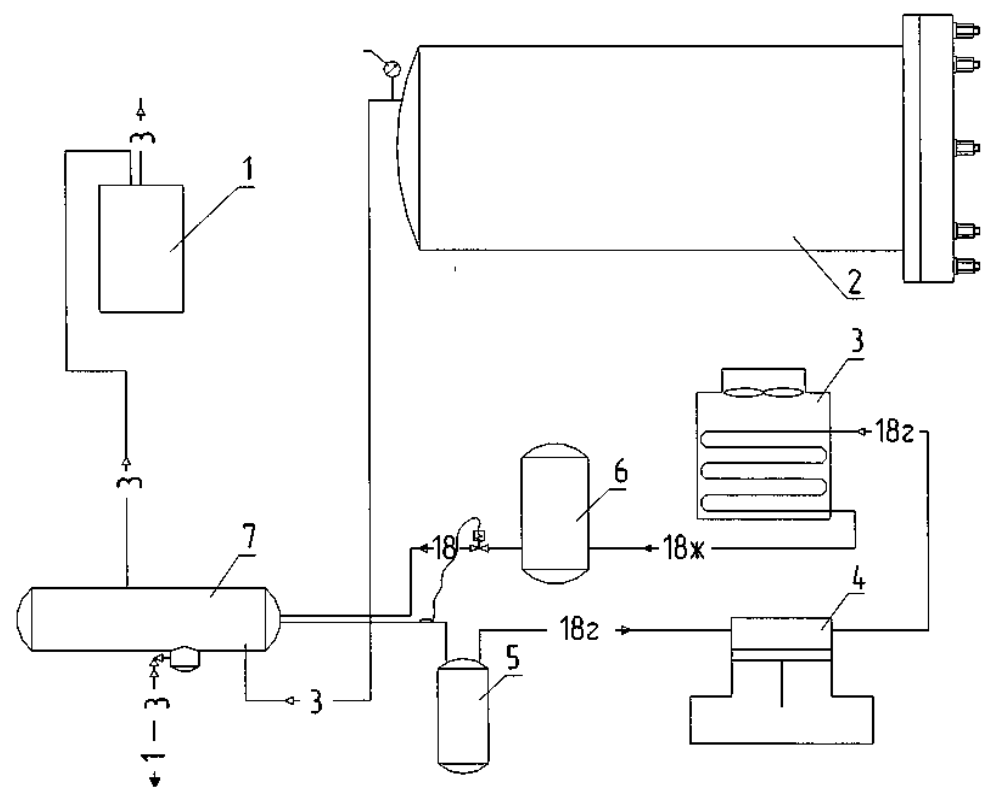

Fig. 2. A diagram of the experimental unit: 1 - vacuum pump; 2 - vacuum chamber; 3 - compressor; 4 - condencer; 5 - liquid separator; 6 - desublimator; 7 - reciever; 8 - vacuum gauge; 9 temperature regulating valve; 18 - system of a cooling agent; $18 \Gamma-$ vapour cooling agent; $18 \%-$ liquid cooling agent. 
To supply heat, two infrared lamps (KGT 220 - 1000, each of them with the output capacity of $1 \mathrm{~kW}$ ) were installed in the vacuum chamber. Two sources of IR-rays provided sufficient and equal heat to a being dried product because the chamber was quite small (36 liter). The vacuum drying chamber is equipped with two infrared lamps placed at the top and at the bottom, at a distance $50-70 \mathrm{~mm}$ from the product (Fig. 2). The infrared heat supply makes it possible to keep a stable product temperature when vacuum drying.

The behavior of a product weight was controlled with the help of electronic weight measuring gauges (tensometers) installed inside the chamber. The residual pressure was set by a pressure gauge, the temperature inside the chamber, in the product and on its surface was set by thermal sensors. The experiments were focused on principal factors affecting the dewatering process. A review of literature has demonstrated that these factors include the heating output capacity of $400 \mathrm{~W}$ and $600 \mathrm{~W}$; a heating temperature of $45^{\circ} \mathrm{C}, 60{ }^{\circ} \mathrm{C}$ and 90 ${ }^{0} \mathrm{C}$; an input and final percentage of dry substances in the product; the thickness of a sample layer $5 \mathrm{~mm}$ and $10 \mathrm{~mm}$.

\section{Results and Discussion}

The objects under study with individual organoleptic properties, chemical composition, physical and chemical characteristics depend on the production technology of a main product. Their principal characteristic is a low percentage of fat and a high percentage of dry substances in the form of milk protein and lactose whey fractions.

The study was focused on the behavior of chemical composition and properties in the objects under consideration. Lactose is a key component in dry substances of whey (4.2 $4.7 \%$ ), that is approximately $70 \%$ of all dry substances in whey. Other components of the milk residue have about $30 \%$. In general, the percentage of main components in the object under consideration can be written as follows: lactose $(4.1)>$ protein substances $(1)>$ minerals $(0.65)>$ fat $(0.25)$. To conclude, dry substances consist generally of milk protein, fat, carbohydrates, which bind a certain amount of water.

When experimenting, the behavior of the object was assessed according to its temperature and the process time. The findings of the experiments related to the weight of cheese and curd whey, heating temperature in the processing chamber and in the product are given as graphs (Fig. 3 A and B).

The thickening was carried out till a maximal percentage of dry substances $-30 \%$; this parameter was assessed according to the weight loss of an object and initial percentage of dry substances.

The technology of conservation relies on the partial or full water removal from an object. A shortage of available water slows down unwanted diffusion, chemical, biochemical reactions, which worsen the quality of a product $[8,41]$.

When dewatering, properties of the initial whey tend to change. In particular, we observed one of the main physical and chemical parameters of a product - acidity. This characteristic depends on acid salts and proteins contained in whey. Unlike the $\mathrm{pH}$ index, the titratable acidity is sensitive to free and bound ions of hydrogen [16]. If whey gets five times thicker, the osmotic pressure increases up to $7.4 \mathrm{MPa}$, i.e. it is 10 times higher and creates unfavorable conditions for the development of microorganisms. Milk acid has an inhibitive effect on microorganisms.

The data demonstrate that a rising concentration of dry substances increases the titratable acidity in the finished product. Here the coefficient of thickening approximates to $K=4.6$. The concentration of dry substances goes up as water is evaporated from the object. A whey concentrate containing $30 \%$ dry substances had the acidity of $380 \mathrm{~T}$, it was $260 \mathrm{~T}$ for a lower concentration of dry substances $(26 \%)$ and $150 \mathrm{~T}$ for the concentration of dry substances of $11.2 \%$. 
A visual analysis revealed no denaturation of whey proteins when concentrating. Native properties of whey and physical and chemical state of whey components are constant if the concentration of dry substances is $30 \%$.

Temperature in the vacuum chamber $60^{\circ} \mathrm{C}$

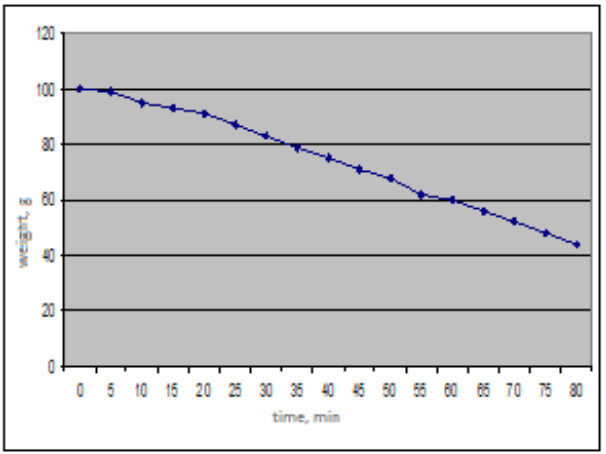

A

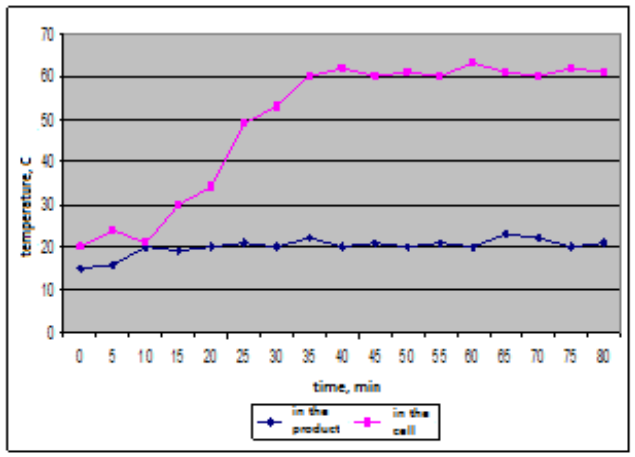

B

Fig. 3. The dynamics of vacuum thermal radiation dewatering of curd whey: weight changes - A, temperature in the processing chamber $-\mathrm{B}$.

The data demonstrate that a rising concentration of dry substances increases the titratable acidity in the finished product. Here the coefficient of thickening approximates to $\mathrm{K}=4$.6. The concentration of dry substances goes up as water is evaporated from the object. A whey concentrate containing $30 \%$ dry substances had the acidity of $380 \mathrm{~T}$, it was $260 \mathrm{~T}$ for a lower concentration of dry substances $(26 \%)$ and $150 \mathrm{~T}$ for the concentration of dry substances of $11.2 \%$.

A visual analysis revealed no denaturation of whey proteins when concentrating. Native properties of whey and physical and chemical state of whey components are constant if the concentration of dry substances is $30 \%$.

After completion of experiments, organoleptic and physical and chemical whey characteristics were studied. The organoleptic characteristics of whey are given in Table 1.

The findings of the study were used as a basis to develop a technology of wheycontaining drinks with long-storage concentrates. The assortment of whey drinks is quite wide. A variety of fermenting microorganisms and their combinations and blends, as well as sugar, fruit and berry fillings expand a group of dairy products. The manufacture of certain products require the use of thermophilic and mesophilic lactic streptococci and acidophilic bacteria with a high antagonistic activity towards disease-causing and potentially pathogenic microorganisms.

Table 1. Organoleptic properties of whey concentrates.

\begin{tabular}{|c|c|c|c|c|}
\hline \multirow[t]{2}{*}{ Parameters } & $\begin{array}{l}\text { Mass fraction } \\
\text { of dry } \\
\text { substances in } \\
\text { the input }\end{array}$ & \multicolumn{3}{|c|}{$\begin{array}{l}\text { Mass fraction of dry substances in a whey } \\
\text { concentrate. } \%\end{array}$} \\
\hline & $6.5 \pm 1$ & $11.2 \pm 0.2$ & $26 \pm 0.5$ & $30 \pm 0.5$ \\
\hline Taste and flavour & Pure. sour-milk & Slightly sour & Sour-sweet & $\begin{array}{l}\text { Sour-sweet with a } \\
\text { strong whey flavor. } \\
\text { no foreign flavors }\end{array}$ \\
\hline $\begin{array}{l}\text { Appearance and } \\
\text { consistency }\end{array}$ & $\begin{array}{l}\text { Homogenous } \\
\text { liquid. no solid }\end{array}$ & $\begin{array}{l}\text { Creamy } \\
\text { consistency. }\end{array}$ & $\begin{array}{l}\text { Viscous. thick. } \\
\text { homogenous }\end{array}$ & $\begin{array}{lr}\text { Thick. } & \text { viscous. } \\
\text { quite } & \text { liquid. }\end{array}$ \\
\hline
\end{tabular}




\begin{tabular}{|l|l|l|l|l|}
\hline & & $\begin{array}{l}\text { liquid. } \\
\text { protein } \\
\text { sediment }\end{array}$ & $\begin{array}{l}\text { with a more } \\
\text { apparent protein } \\
\text { sediment }\end{array}$ & homogenous \\
\hline Colour & $\begin{array}{l}\text { Light green. } \\
\text { similar in the } \\
\text { whole product }\end{array}$ & $\begin{array}{l}\text { Green- } \\
\text { yellow. } \\
\text { similar in the } \\
\text { whole } \\
\text { product }\end{array}$ & $\begin{array}{l}\text { Light yellow. } \\
\text { similar in the } \\
\text { whole product }\end{array}$ & $\begin{array}{l}\text { Bright yellow. a } \\
\text { brown shade }\end{array}$ \\
\hline
\end{tabular}

The carried out research helped develop a technology of whey-containing products on the base of concentrates. The assortment of whey-containing drinks is wide. A variety of fermenting microorganisms, their combinations and blends, multicomponent probiotic starters, sugar, fruit and berry fillings can expand the group of fresh and fermented wheycontaining drinks. Special attention is to be paid to the health of population, so thermophilic and mesophilic lactic streptococci and acidophilic bacteria with a high antagonistic activity towards disease-causing and potentially pathogenic microorganisms were used as a bacterial starter when preparing new drinks.

New ready to drink whey-containing products have valuable dietary and medical properties. They are intended to improve functions of stomach, lever and human body metabolism. Therefore, they are highly recommended as a diet component of children and people suffering from different diseases. The study suggests new recipes and technologies on the base of whey concentrates. They can be added into a milk mixture of fermented drinks, a milk mixture can be soured by pure lactic-acid bacteria or aroma and flavor substances can be admixed into a cooled curd. The production of whey-containing drinks is to be organized according to the accepted process flow patterns and technological regulations, requirements specified in GOST or branch standards for the manufacture of whey drinks.

\section{Conclusion}

The milk-processing branch, its wastewater in particular, influences the environment. The complex industrial recycling of waste - by-products in milk-processing is a core measure to make the dairy industry more environmentally friendly. Significant amounts of whey produced in Russia are to be used in core production processes, for the output of additional products, because they can help neutralize harmful effects of milk processing wastewaters on the environment. The process factors of whey dewatering in the manufacture of whey concentrates were studied. The concentrates with a mass percentage of dry substances up to $30 \%$ were produced owing to the innovative vacuum and thermal radiation method. The study revealed the dynamics of vacuum-induced water evaporating from cheese and curd whey in appropriate modes, regularities and specifics of water removal. The quality of concentrates was assessed according to key parameters. The organoleptic properties of sample concentrates met all criteria quite sufficiently, being almost similar to input parameters. The whey concentrates with a mass fraction of dry substances from 11 to 30.0 $\%$ are recommended as a recipe component of fresh and fermented whey-containing drinks. The use of IR-rays represents a good alternative to the conventional thickening and drying processes. Non-destructive temperature modes of the vacuum dryer have no negative effect on the properties of input raw materials.

\section{References}

1. A.N. Ponomarev, E.I. Melnikova, E.V. Bogdanova, Dairy Industry 7, 38-39 (2018) 
2. A.G. Khramtsov, Technics and technology of food production 3, 48 (2018)

3. T.A Volkova, Yu.Yak. Sviridenko, Processing of milk 5, 6-9 (2014)

4. I.V. Buyanova, S.M. Lupinskaya, I.A. Smirnova, I.A. Maseeva, EST 2018 IOP Conf. Series: Earth and Environmental Science 224, 012007 (2019) doi:10.1088/17551315/224/1/012007

5. V.V. Makarenko, D.S. Dranikov, Eurasian Union of Scientists 10-5, 19 (2015)

6. T.A. Krasnova, A.K. Gorelkina, N.V. Gora, N.S. Golubeva, I.V. Timoschuk, I.V. Buyanova, Theoretical and Applied Ecology 2, 51-56 (2020)

7. L.M. Makarova, E.A Bobina, System management 4, 8 (2013)

8. A.G Ibragimov, Prirodoobustroystvo 2 (2014)

9. M.P. Shchetinin., A.S. Dorokhova, Polzunovsky Bulletin 4-4, 80 (2013)

10. V.V. Makarenko, International scientific journal 1, 37-40 (2016)

11. I. Korotkiy et al., Technics and technology of food production, 2, (2019)

12. A.Ju. Prosekov, E.V. Ul'rih, V.G. Budrik, S.G. Botina, E.Ju. Agarkova, International Journal of Applied and Fundamental Research 1, 3 (2013)

13. I.V. Buyanova, S.M. Lupinskaya, I.A. Mazeeva, L.A. Ostroumov, International Conference on Production and Processing of Agricultural Raw Materials, IOP Conference Series: Earth and environmental science 640, 032007 (2021) https://iopscience.iop.org/article/10.1088/1755-1315/640/3/032007/pdf

14. I.A. Evdokimov et al., Bulletin of the North Caucasus Federal University 6, 917 (2017)

15. M.S. Zolotoreva et al., Dairy industry 7, 36-37 (2018)

16. A.A. Varivoda, International scientific research journal 2-1, 21 (2014).

17. I.V. Buyanova, I.V. Altukhov, N.V.Tsuglenok, O.V. Krieger, E.V. Kashirskih, Foods and Raw Materials 7, 151-160 (2019) 